\title{
ANALISIS KESULITAN GURU DALAM MENGIMPLEMENTASIKAN KURIKULUM 2013 DALAM PROSES PEMBELAJARAN MATEMATIKA DI MTS BABUSSALAM
}

\author{
${ }^{1}$ Asep Sugiandi, ${ }^{2}$ Ana setiani, M.Pd \\ ${ }^{12}$ Program Studi Pendidikan Matematika, fakultas Pendidikan dan IlmuPendidikan, Universitas \\ Muhammadiyah Sukabumi

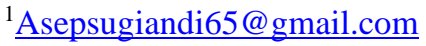 \\ 2ana.setiani.math@gmail.com
}

\begin{abstract}
ABSTRAK
Munculnya ide penelitian ini karena adanya kesulitan guru matematika dalam mengimplementasikan kurikulum 2013 dan bertujuan untuk mengetahui kesulitan apasajakah yang dihadapi guru matematika dalam mengimplementasikan kurikulum tersebut. Jenis penelitian yang digunakan adalah penelitian kualitatif dimana hasil yang didapatkan berupa kata-kata tertulis dan data yang diamati dari lapangan. Subjek yang diamati adalah guru matematika di sekolah. Teknik pengumpulan data yang dilakukan yaitu wawancara dan angket. Dari hasil penelitian yang diperoleh melalui wawncara menunjukan bahwa ditemukan adanya kesulitan guru yang dihadapi adalah (1) guru masih kurang kreaktif dalam pelaksaan proses pembelajaran dan guru masih mendominasi di kelas. (2) siswa kurang berpera naktif sehingga guru kesulitan dalam mengaktifkan suasana di kelas. Dari hasil penelitian melalui angket yang diberikan kepada guru, guru mengalami kesulitan dalam hal penilaian. Dimana memiliki persentase sulit yang paling tinggi dalam penilaian $40 \%$, dalam perencanaan memiliki persentase $33 \%$ dan dalam tahap pelaksanaan memiliki persentase $20 \%$. Penelitian dapat disimpulkan bahwa kurikulum 2013 sudah di implementasikan dengan baik namun guru masih mengalami kesulitan dalam prosespelaksanaan pembelajaran dan penilaian.
\end{abstract}

Kata kunci : implementasi, kurikulum 2013, kesulitan.

\section{PENDAHULUAN}

Penelitian ini dilakukan karena munculnya kesulitan-kesulitan yang dihadapi oleh guru dalam hal mengimplementasikan kurikulum 2013. Dimana penggunaan kurikulum 2013 sangat berpengaruh dalam mata pelajaran matematika hal inilah juga membuat adanya pengaruh terhadap hasil peserta didik dalam matematika. Pada saat ini peneliti ingin mengetahui kesulitan apa saja yang di hadapi oleh guru sehingga peneliti melakukan penelitian tentang analisis kesulitan guru dalam mengimplementasi kurikulum 2013 dalam proses pembelajarn matematika di MTS Babussalam.

Penelitian ini sebelumnya dilakukan oleh Utami ningsih dan Sumardi daengan judul analisis kesulitan guru matematika kelas VII dalam menerapakan kurikulum 2013 di SMP N 12 SURAKARTA. Hal tersebut yang membuat peneliti tertarik ingin mengetahui persamaan atau pebedaaan apa saja kesulitan yang dihadapi guru dalam mengimplementasikan kurikulum 2013 di sekolah dan tempat yang berbeda.

\section{LANDASAN TEORI}

Menurut Kemendikbud (2013: 210) menyatakan bahwa Kurikulum 2013 menekankan pada dimensi pedagogik modern dalam pembelajaran, yaitu menggunakan pendekatan ilmiah (scientific approach) dalam pembelajaran semua mata pelajaran (tematik terpadu), dan proses mendapatkan dan mengumpulkan informasi dilakukan dengan penilaian otentik. Kurikulum 2013 adalah kurikulum terbaru yang diluncurkan oleh Departemen Pendidikan Nasional mulai tahun 2013 sebagai bentuk pengembangan dari kurikulum sebelumnya yaitu kurikulum 2006 atau Kurikulum Tingkat Satuan Pendidikan yang mencangkup kompetensi sikap, pengetahuan, dan keterampilan secara terpadu. Berdasarkan beberapa pendapat yang dikemukan diatas, bahwa dapat disimpulkan arti dari Kurikulum 2013 adalah kurikulum 
yang dibuat untuk memperbaiki kurikulum KTSP yang didalamnya terdapaat suatu rencana yang disusun untuk melancarkan proses belajar-mengajar berbasis karakter dan kompetensi dengan karakteristik pembelajaran menerapkan pendekatan ilmiah (scientific approach), pembelajaran bersifat tematik terpadu, dan penilaian otentik.

\section{METODE PENELITIAN}

Metode penelitian yang digunakan adalah penelitian kualitatif. Penelitian kualitatif menghasilkan data deskriptif berupa kata-kata tertulis atau data- data yang didapat dari hasil angket. Penelitian ini menekankan pada keadaaan yang sebenarnya terjadi dilapangan sehingga mendapatkan data yang valid dan dapat di pertanggung jawabkan kebenarannya. Kemudian untuk desain penelitian studi kasus dalam arti penelitian difokuskan pada satu fenomena saja yang dipilih dan ingin dipahami secara mendalam, dengan mengabaikan fenomena-fenomena lainnya. Penomena ini terjadi pada guru matematika yang memiliki kesulitan dalam mengimplementasikan kurikulim 2013. Subjek penelitian merupakan guru matematika di sekolah dan instrumen yang digunakan adalah (1) angket dalam penelitian ini peneliti ingin menggunakan angket untuk mengumpulkan data agar penelitian dan hasilnya mudah diolah. Dalam penelitian saat ini, angket akan disajikan dalam bentuk skala Likert dengan menggunakan empat kategori atau alternatif jawaban. Skala Likert ini telah banyak digunakan oleh para peneliti guna mengukur persepsi atau sikap sesorang (Hamid Darmadi, 2011: 106). Untuk mempermudah analisis, empat alternatif jawaban tersebut dibuat nilai dengan skor 4, 3, 2, dan 1. Berikut ini adalah penjelasan skor untuk tiap-tiap alternatif jawaban tersebut.

Tabel 1.1 tabel alternatif jawaban dan skor

\begin{tabular}{|l|l|l|}
\hline $\begin{array}{l}\text { Alternatif } \\
\text { Jawaban }\end{array}$ & Keterangan & Skor \\
\hline SS & Sangat Sulit & 4 \\
\hline S & Sulit & 3 \\
\hline
\end{tabular}

\begin{tabular}{|l|l|l|}
\hline CS & Cukup Sulit & 2 \\
\hline TS & Tidak Sulit & 1 \\
\hline
\end{tabular}

(2) pedoman wawancara yaitu pedoman yang menjadi landasan untuk membuat pertanyaan kepada responden. Selanjutnya teknik analisis data, dimana untuk menganalisis data penelitian yang berhubungan dengan kesulitan guru dalam mengimplementasikan kurikulum 2013 dalam proses pembelajaran matematika, maka peneliti menggunakan prosedur (1) memberikan angket kepada guru matematika di sekolah untuka mendapatka data yang sebenarnya terjadi supaya mudah di olah. (2) melakukan wawancara kepada guru untuk mengetahui fakta dan realita yang terjadi di sekolah tersebut. Kemudian data dianalisis yang kemudian data diinterprestasikan kedalam bentuk presentase. Untuk menghitung data persentase masing-masing ketegori digunakan rumus sebagai berikut.

$$
P=\frac{F}{N} \times 100 \%
$$

Keterangan :

$\mathrm{P}$ : angka persentase yang di cari

F : frekuensi jawaban

$\mathrm{N}$ : number of case

(jumlah

frekuensi/banyaknya

data individu)

\section{HASIL DAN PEMBAHASAN}

\section{Hasil Penelitian}

Berikut ini merupakan hasil pengolahan data yang didapat melalui angketangket yang diberikan kepada guru matematika di sekolah tersebut.

Tabel 1.1 deskripsi frekuensi persentase tingkat kesulitan guru dalam menggunakan kurikulum 2013

\begin{tabular}{|c|c|}
\hline Dimensi & $\begin{array}{c}\text { Frekuensi tingkat } \\
\text { kesulitan }\end{array}$ \\
\hline
\end{tabular}




\begin{tabular}{|c|c|c|c|c|}
\hline $\begin{array}{l}\text { kesulita } \\
\text { n }\end{array}$ & SS & $\mathbf{S}$ & CS & TS \\
\hline $\begin{array}{l}\text { Perencan } \\
\text { aan }\end{array}$ & 8 & 5 & 7 & 3 \\
\hline $\begin{array}{l}\text { Pelaksan } \\
\text { aan }\end{array}$ & 4 & 3 & 8 & 4 \\
\hline Penilaian & 8 & 6 & 4 & 4 \\
\hline Jumlah & 20 & 15 & 18 & 11 \\
\hline \multicolumn{5}{|c|}{ Persentase } \\
\hline $\begin{array}{c}\text { Perencan } \\
\text { aan }\end{array}$ & $\begin{array}{l}40 \\
\%\end{array}$ & $\begin{array}{l}33 \\
\%\end{array}$ & $\begin{array}{c}38,89 \\
\%\end{array}$ & $\begin{array}{c}27,28 \\
\%\end{array}$ \\
\hline $\begin{array}{c}\text { Pelaksan } \\
\text { aan }\end{array}$ & $\begin{array}{l}20 \\
\%\end{array}$ & $\begin{array}{l}20 \\
\%\end{array}$ & $\begin{array}{c}44,44 \\
\%\end{array}$ & $\begin{array}{c}36,36 \\
\%\end{array}$ \\
\hline Penilaian & $\begin{array}{c}40 \\
\%\end{array}$ & $\begin{array}{l}40 \\
\%\end{array}$ & $\begin{array}{c}22,23 \\
\%\end{array}$ & $\begin{array}{c}36,36 \\
\%\end{array}$ \\
\hline
\end{tabular}

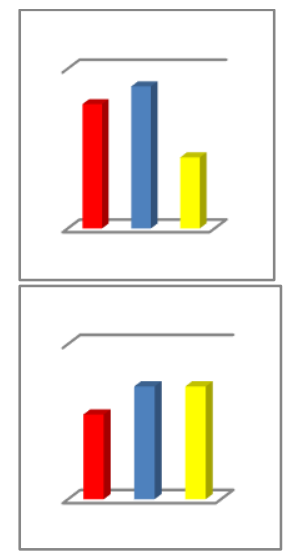

Dari tabel diatas terlihat bahwa guru mengalami kesulitan dalam hal penilaian. Dimana memiliki persentase sulit yang paling tinggi dalam penilaian $40 \%$, dalam perencanaan memiliki persentase $33 \%$ dan dalam tahap pelaksanaan memiliki persentase $20 \%$.

Selanjutnya hasil peneliti melalui wawancara Berikut merupakan hasil penelitian yang dilakukan melalui wawancara :

1. Perencanaan pembelajaran

Dalam kegiatan perencanaan pembelajaraan guru menyusun RPP yang telah di buat guru sebelumnya saat masa libur sekolah sebelum ajaran baru kembali di mulai. Hal ini terbukti dengan adanya hasil wawancara yang dilakukan oleh peneliti.

2. Pelaksanaan pembelajaran

Setelah melakukan perencanaan pembelajaran, guru mulai melaksanakan perncanaan pembelajaran yang didalam nya terdapat kegiatan awal, inti, dan akhir yang sudah tersusun dan tertera dalam RPP, namun dal hal guru mengalami kesulitan karena siswa kurang aktif dalam bertanya.

3. Penilaian

Dalam penilaian terdapat 3 aspek penilaian yang meliputi penilaian sikap, pengetahuan dan keterampilan.

a. Penilaian sikap

Dalam penilian sikap guru melakukannya dengan observasi pada saat pembelajaran di sekolah.

b. Penilaian pengetahuan

Dalam melakukan penilain ini guru melakukannya dengan soal tertulis dari buku paket. 
c. Penilaian keterampilan

Guru melakukan penilaian keterampilan dengan memberikan tugas tambahan berupa pembuatan bangun ruang di kertas karton.

\section{Pembahasan}

Dalam menggunakan Kurikulum 2013 guru mengalami beberapa kesulitan dalam menerapkan kurikulum tersebut hal ini terlihat dari observasi dan angket yang dilakukan peneliti kepada guru matematika kelas VII di MTS Babussalam. Adapun kesimpulan dari hasil wawancara yang telah dilakukan kepada guru mata pelajaran matematika kelas VII yaitu bapak Kamaludin dan bapak Sukowahyono, dengan tujuan dari wawancara ini untuk mengetahui kesulitan guru dalam menerapan Kurikulum 2013 baik secara teknik, pelaksanaan, dan kendalanya. Adapun hasil wawancara dengan bapak Kamal selaku guru mata pelajaran matematika adalah sebagai berikut:

1. Proses pembelajaran yang dilakukan di kelas menggunakan pendekatan scientific.

2. Sarana dan prasarana yang digunakan adalah RPP dan buku guru dan lain-lain.

3. Evaluasi yang digunakan yaitu penilaian sikap, pengetahuan dan keterampilan.

Sedangkan untuk kesulitan guru matematika kelas VII dalam menerapkan kurikulum 2013 di MTS Babussalam berdasarkan hasil angket guru adalah guru Press. sudah menerapkan Kurikulum 2013 dengan baik namun guru masih mengalami kesulitan dalam penilaian hal tersebut dapat dilihat dalam tabel hasil penelitian.

\section{KESIMPULAN}

Berdasarkan hasil penelitian yang dilakukan penerapan kurikulum 2013 sudah sesuai dengan yang di rencanakan hal ini terjadi karena guru sering mengikuti pelatihan tentang pendidikan yang sudah di buat oleh KEMENDIKBUD. Adapun hal yang membuat kurang efektif dalam pembelajaran yaitu dari peserta didik sendiri dimana peserta didik kurang berperan aktif dalam prose pembelajaran shingga guru kesulitan dalam mengefektifkan proses pembelajaran, hal ini membuat guru juga harus memotifasi peserta didik agar berperan aktif dalam pembelajaran sedangakn faktor dari guru yaitu guru masih memiliki kesulitan dalam hal penilaian autentik.

\section{DAFTAR PUSTAKA}

Moleong, J. Lexy. (2011). Metodologi Penelitian Kualitatif. Bandung. PT Remaja

Mulyasa, E. (2014). Pengembangan Implementasi Kurikulum 2013. Bandung. PT Remaja Rosdakarya.

Muzamiroh, Mida Latifatul. (2013). Kupas Tuntas Kurikulum 2013. Kata Pena.

Sutopo, H.B. (2002). Metodologi Penelitian Kualitatif. Surakarta. Sebelas Maret Unviversity 